\title{
Matematik Dersi Öğretim Programının Matematik Öğretmenlerinin Görüşleri Açısından Analizi: Matematiksel Süreç Becerileri, Öğretim Yaklașımları ve Ölçme-Değerlendirme Boyutu
}

\author{
Özgür Şen ${ }^{1}$, \& Şeref Mirasyedioğlu ${ }^{2}$
}

\begin{abstract}
Özet: Bu araştırma, ilköğretim matematik öğretmenlerinin görüşlerine göre 2005 yılı matematik dersi öğretim programlarının matematiksel süreç becerileri, öğretim yaklaşımları ve ölçme-değerlendirme yaklaşımlarını incelemeyi amaçlamaktadır. Bu amaçla çalışmada, nitel araştırma yöntemi kullanılmıştır. Çalışma grubunu belirlemede, amaçlı örnekleme yöntemlerinden ölçüt örnekleme yöntemi kullanılmıştır. Çalışmaya, Ankara ilinde görev yapan 24 ilköğretim matematik öğretmeni katılmıştır. Bu bağlamda, uzman görüşleri alınarak tasarlanan görüşme formu aracılığıyla öğretmenler ile yarı yapılandırılmış mülakatlar yapılmıştır. Veriler, NVivo 10 Nitel Analiz Programı kullanılarak analiz edilmiştir. Çalışmanın sonucunda, matematik öğretmenleri öğrencilerin matematiği günlük hayatla ilişkilendirme, akıl yürütme ve problem çözme becerilerinin yetersiz olduğu görüşünde oldukları tespit edilmiştir. Ayrıca matematik öğretmenleri öğretim yaklaşımlarını uygulama süreçlerinde kalabalık sınıflar, zaman, müfredat yoğunluğu, lise sınavlarına hazırlık vb. sorunlarla karşılaştıkları belirlenmiştir.
\end{abstract}

Anahtar Kelimeler: Matematik Dersi Öğretim Programı, Öğretmen Görüşleri, Matematiksel Süreç Becerileri, Öğretim Yaklaşımı, Ölçme-Değerlendirme

Geliş Tarihi: 30.07.2019 - Kabul Tarihi: 29.02.2020 - Yayın Tarihi: 29.06.2020

DOI: $10.29329 / \mathrm{mjer} .2020 .258 .15$

\section{Analysis of Mathematics Curriculum in Terms of Mathematics Teachers' Perspectives:}

\section{Mathematical Process Skills, Teaching Approach, and Measurement-Assessment Dimension}

\begin{abstract}
This study aims to investigate the mathematical process skills, teaching approaches and measurement and evaluation approaches available in 2005 mathematics curriculum based on primary education mathematics teachers' views. The study employs a qualitative research method for this purpose. It uses criterion sampling, a method of purposeful sampling, in forming the study group. 24 primary education mathematics teachers working in Ankara were included in the study. In this context, semi-structured interviews were held with the participants through the interview forms which were designed on the basis of expert opinion. The data were analysed on the
\end{abstract}

\footnotetext{
* Bu çalışma, ilk yazar tarafından hazırlanan doktora tez çalışmasından üretilmiştir.

${ }^{1}$ Ozgür Şen, Assist. Prof., Mathematics Education, Bozok University, ORCID: 0000-0002-8177-0984

Correspondence: senozgur@yahoo.com

${ }^{2}$ Şeref Mirasyedioğlu, Prof. Dr., Eğitim Fakültesi, Başkent Üniversitesi, ORCID: 0000-0001-9492-5992
} 
NVivo 10 Qualitative Analysis programme. The results obtained demonstrated that mathematics teachers held the view that students' skills of associating mathematics with daily life and their reasoning and problem-solving skills were inadequate. Besides, mathematics teachers also stated that they encountered such problems as crowded classrooms, lack of time, too intensive programmes and preparation for high school entrance examinations in implementing the teaching approaches.

Keywords: Mathematics Curriculum, Teachers' Views, Mathematical Process Skills, Teaching Approach, Measurement and Evaluation

\section{GíRiş}

Geleneksel matematik öğrenme ve öğretme yaklaşımı ile yetişen öğrenciler kendi öğrenme süreçlerinden sorumlu olma, problem çözme, araştırma, yaratıcılık, bağısız düşünme gibi beceriler ile yetiştirilmediğinden gerçek yaşamda karşılaştıkları durumlarda çözüm üretmekte zorlanırlar (Açıkgöz, 2003). Günümüzde yetiştirilen bireylerin hayatında matematiği kullanabilen, problem çözen, çözüm ve düşüncelerini paylaşacak nitelikte yetişmesi gerektiği vurgulanmaktadır (Millî Eğitim Bakanlığ1, 2005). Bu nedenle yenilikçi eğitim anlayışı ile yetişen bireylerin bilgiyi yeni bilgiler edinmek için kullanması, olayların derinliğini anlayabilmesi, muhakeme yapabilme, bilimsel düşünme ve zihinsel becerilerini kullanması beklenmektedir (Orbeyi ve Güven, 2008).

Matematik bireyi bilgi, beceri ve zihin faaliyetlerini toplumda başarılı ve ödüllendirici bir katılım için gerekli olan alışkanlıklar ile donatır. Hayatları boyunca öğrenciye hizmet edecek şekilde matematik öğrenmek; beceri, bilgi ve zihinsel faaliyetler ile matematik işlemlerini uygulamak, geliştirmek ve matematiğe karşı olumlu tutum kazanmak için matematiksel anlayışı geliştirmelerine yardımcı olan sınıf deneyimlerine ihtiyaç vardır (Ontario, 2005). English ve Halford (2012), matematik eğitiminin en önemli amaçlarından birini öğrencilerin matematiği anlamaları olduğunu belirtmişlerdir. Altun (2004), matematik öğretiminin amacını, kişiye günlük hayatın gerektirdiği matematiksel bilgi ve becerileri kazandırmak, onlara problem çözmeyi öğretmek ve olayları problem çözme yaklaşımı içinde ele alarak bir düşünce biçimi kazandırmak olduğunu söylemektedir.

Matematik eğitimin kalitesini artırmada öğretim programlarının önemli bir yere sahiptir. Türkiye'de ders programlarını geliştirme çalışmaları Cumhuriyet'in ilanı ile birlikte dönemin ihtiyaç ve beklentilerine uygun olarak düzenlenmiştir (Sezgin-Memnun, 2013). Öğretim programları toplumların sosyal, kültürel ve ekonomik yönlerden gelişmesi ve bireylerin kendilerini tanımlarında önemli bir role sahiptir (Akınoğlu, 2005). Bu nedenle öğretim programlarının gereksinimler değiştikçe yeni biçimler almakta, planlı ve sürekli olarak gelişmeye açık tutulması gerekmektedir (Fer, 2005). 1924 yılından itibaren ülkemizde program geliştirme çalışmaları devam etmektedir. Daha sonraları 1926, 1936, 1948, 1954, 1968, 1982, 1990 ve 2004 yıllarında programlarda önemli değişiklikler yapılmıştır (Ulutaş ve Erman, 2011). 2004 yılından sonra Millî Eğitim Bakanlığı okul programlarında 
köklü bir program değişikliğine gitmiştir (Babaoğlan ve Olkun, 2006). Ülkemizde uzun zamandır öğretmen merkezli eğitim sistemi öğrenci merkezli sistem haline dönüştürülme çalışması gerçekleştirilmiştir. Bir yıl gibi kısa sürede hazırlanan öğretim programları yine bir yıl gibi kısa zamandaki pilot uygulamaları sonucu ile bu süre zarfında uygulamaya katılan idareci, öğretmen, veli ve müfettişlerin görüşleri doğrultusunda değerlendirilerek uygulamaya geçilmiştir.

Öğretim programlarının verimliliğinin artması ve gelişimine katkı sağlamak amacıyla sürekli değerlendirilmesi ve gözden geçirilmesi gerekmektedir. Çünkü uygulanmakta olan programın ne derecede etkili olduğu, amacına uygun şekilde devam edip etmediği, eksikliklerinin belirlenmesi öğretim programlarının etkililiğine yol göstermektedir (Marsh ve Willis, 2007). Matematik dersi öğretim programları belli aralıklarla incelenmesi, sistematik olarak gözden geçirilmesi gerekmektedir (National Counsil of Teachers Mathematics [NCTM], 2000).

Yenilmez ve Sölpük (2014), Yükseköğretim Kurulu Ulusal Tez Merkezindeki matematik dersi öğretim programlarının değerlendirilmesine yönelik 2004-2013 yılları arasındaki yüksek lisans ve doktora çalışmalarının çoğunlukla 2007-2008 yıllarında yapıldığını ve en sık nicel araştırma yönteminin kullanıldığ 1 çalışmalar olduğunu tespit etmişlerdir. Araştırmalar, ilköğretim matematik programının değerlendirilmesi ile ilgili olan çalışmalarının yoğunluklu olarak programın okullarda uygulanmaya başlamasını izleyen yıl gerçekleştiğini zamanla yapılan çalışmalarda kademeli olarak azalma içerisinde olduğu göstermektedir (Kablan, 2011). Öğretim programlarının tasarlanmasının ve uygulamasının yanında yenilenen programlarının belli sürelerde dönütlerinin alınması ve bu dönütlerin 1şı̆̆ında gerekli düzeltmelerin yapılması da o derece önemlidir (Romberg ve Sharfer, 2003). Program değerlendirme, eğitim programının yenileşmesi, gelişmesi ve yürütülmesini desteklemek için geliştirilir ve programın sürekliliğini sağlamaya çalışır (Özdemir, 2009). Bu nedenle, program değerlendirme çalışmalarında öğretim programların amaçlarına uygun şekilde ilerleyip ilerlemediğine dair uygulayıcıların görüşleri büyük önem taşımaktadır. Öğretim programlarının istenilen başarıya ulaşmasında sorumluluğu üslenen öğretmenlerin görüşleri, tecrübeleri ve bilgileri oldukça önemlidir. $\mathrm{Bu}$ araştırma 2005 y1lından sonra uygulanmaya başlayan ilköğretim 6-8. sınıflar matematik dersi öğretim programlarının matematik dersinin kazandırmayı hedeflediği matematiksel beceriler, öğretim yaklaşımları ve ölçme değerlendirme boyutuna ilişkin öğretmenlerin görüşlerini incelemeyi amaçlamaktadır.

\section{Araştırmanın Önemi}

Programı değerlendirme, programın etkili ve verimli şekilde yürütülmesi ayrıca istenilen hedeflere ne düzeyde ulaşıldığı, programın eksik ve düzeltilmesi gerek yönlerinin tespiti açısından önemlidir (Uşun ve Karagöz, 2009). Her program geleceğimiz olan çocuklarımıza doğru, kaliteli, nitelikli ve faydalı olmak amacıyla dünyanın gelişen şartlarına ve getirdiği gelişmelere bağlı olarak belli zaman aralıklarında yenilenmektedir. 2005 yılından bu yana okul müfredatlarında reform 
niteliğindeki yapılanma çalışmasına paralel olarak matematik öğretim programlarının felsefesinden ölçme değerlendirme boyutuna kadar pek çok değişiklik yapılmıştır.

Yapılan bu araştırma, öğrenci merkezi olarak nitelendirilen 2005 yılında yayınlanan matematik dersi öğretim programını değerlendirmeyi amaçlamaktadır. Bu doğrultuda, matematik öğretmenlerinin 6-8. sınıf matematik dersi öğretim programını kazandırmayı hedeflediği beceriler, öğretim yaklaşımları ile ölçme ve değerlendirme yaklaşımlarını kullanma sıklıkları incelenmiştir. $\mathrm{Bu}$ bağlamda aşağıdaki sorulara cevap aranacaktır.

1. İlköğretim matematik öğretmenlerinin matematik dersi öğretim programı matematiksel süreç becerilerine (ilişkilendirme, iletişim, akıl yürütme, problem çözme) ilişkin görüşleri nelerdir?

2. İlköğretim matematik öğretmenlerinin matematik dersi öğretim programı öğretim yaklaşımlarına ilişkin görüşleri nelerdir?

3. İlköğretim matematik öğretmenlerinin matematik dersi öğretim programı ölçme ve değerlendirme yaklaşımlarına ilişkin görüşleri nelerdir?

\section{YÖNTEM}

\section{Araştırmanın Modeli}

Nitel olarak tasarlanan araştırmada görüşme tekniği kullanılarak veri toplanması amaçlanmıştır. Görüşme tekniğini Maxwell (1992), katılımcıların algıları yakalayabilmek King (1994), ise bireylerin kendilerini ifade ederken konu hakkında daha geniş bilgilerin toplanmasına olanak sağlayan esnek bir nitel yöntem olduğunu düşünmektedir. Ayrıca katılımcının deneyim, görüş, düşünce ve algılarını derin biçimde öğrenmemize olanak sağlamaktadır (Tutty, Rothery ve Grinnell, 1996).

\section{Çalışma Grubu}

Örneklem belirlemesinde amaçlı örnekleme yöntemlerinden ölçüt örneklemesi yöntemi kullanılmıştır. Bu örnekleme yönteminde temel anlayış önceden belirlenen bir dizi ölçütü karşılayan durumlar ile çalışılmasıdır (Yıldırım ve Şimşek, 2011 s.112). Bu çalışma için belirlenen ölçütler: a) Gönüllü olmak, b) Matematik öğretim programlarına yönelik yeterli bilgi sahibi olmak, c) 6-8. sınıf düzeylerin her birinde eğitim-öğretim yapmak. Araştırmaya katılan öğretmenlerden araştırma konusu hakkında yeterli bilgilere ulaşılması açısından en az on yıllık deneyim sahibi olmalarının yanında 2005 yılı ve daha önce yayınlanmış matematik programları hakkında bilgi sahip olup derslerinde bu programları uygulamış olmaları istenmektedir. Çünkü 2005 yılında yayınlanan programın diğer programlardan farkını açıkça ortaya koyma, karşılaştırma yapabilme ve değerlendirmeleri açısından önemli olduğu düşünülmektedir.

Araştırmanın verileri, 2013-2014 eğitim öğretim yılı içerisinde toplanmıştır. Bu amaçla araştırmaya katılan öğretmenlerin kıdem durumları dikkate alınarak örneklem belirlenmiştir. 10-14 yıl, 
15- 19 y1l, 20- 24 y1l ve 25 y1l üzeri hizmet kıdemine sahip her bir gruptan 6'şar öğretmen olmak üzere toplam 24 öğretmen ile görüşmeler yapılmıştır. Öğretmenlerin 12'si erkek 12'si bayandır. Eğitim durumlarına bakıldığında 5 tanesi yüksek lisans mezunun olup diğerleri lisans mezunudur. Tablo 1'de araştırmaya katılan öğretmenlerin demografik bilgileri yer almaktadır.

Tablo 1. Araştırmanın Katılan Öğretmenlerin Demografik Özellikleri

\begin{tabular}{llll}
\hline Değişken & & $\mathrm{n}$ & $\%$ \\
\hline Cinsiyet & Kadın & 12 & 50 \\
& Erkek & 12 & 50 \\
& Toplam & 24 & 100 \\
\hline Öğretmenlikteki kıdemi & $10-14$ yıl & 6 & 25 \\
& $15-19$ yll & 6 & 25 \\
& $20-24$ yıl & 6 & 25 \\
& 25 y1ldan fazla & 6 & 25 \\
& Toplam & 24 & 100 \\
\hline Eğitim durumu & Lisans & 19 & 20,8 \\
& Yüksek lisans & 5 & 79,2 \\
& Toplam & 24 & 100 \\
\hline
\end{tabular}

\section{Görüşme Formunun Geliştirilmesi}

Öncelikle görüşme soruları tasarlanmış. Görüşme soruları matematik dersi öğretim programı kazandırmayı amaçladığı matematiksel beceriler, öğrenme yaklaşımı ve ölçme değerlendirme yaklaşımı dikkate alınarak hazırlanmıştır. Kişinin kendisini ifade etme imkânı, gerektiğinde konu hakkında derinlemesine bilgi sağlaması (Büyüköztürk, Kılıç-Çakmak, Akgün, Karadeniz ve Demirel, 2012) nedenlerinden dolayı yarı yapılandırılmış olarak hazırlanmıştır. İlk olarak tasarlanmış görüşme soruları için pilot uygulama yapılmıştır. Fazla ve anlaşılması kavram yanılgısı oluşturacak sorular formdan çıkarılmıştır. Tasarlanmış görüşme soruları gerekli düzenlemeler yapıldıktan sonra geçerlilik ve güvenirlilik için ön uygulamalar yapılmıştır. Geliştirilen soruların ön uygulaması araştırma grubu dışındaki dört matematik öğretmenine (ikisi eğitim fakültesi, ikisi fen fakültesi) uygulanmıştır. Uygulama sonuçları değerlendirilip gerekli geliştirme ve düzenlemeler yapıldıktan sonra görüşme sorularına son hali verilmiştir. Araştırma için geliştirilen görüşme soruları içeriği ve yapısı hakkında iki profesör, iki araştırma görevlisi ve bir dil uzmanından uzman görüşü alınarak gerekli değişiklikler yapılmıştır. Bu süreç soruların yapı ve içerik olarak geçerli olmasına kanıt olarak gösterilebilmektedir.

\section{Veri Toplama Süreci ve Verilerin Analizi}

Görüşmeler farklı okullardaki öğretmenlerle gönüllülük ilkesine bağlı olarak ve okul idaresinden izin alınarak uygun bir ortamda yapılmıştır. Görüşmeler başlamadan önce görüşme yapılacak öğretmene; araştırmanın amacı, önemi, elde edilen verilen hangi amaçla kullanılacağı, verilerin gizliliği, katılımcının isimlerinin gizli kalacağı, görüşmenin ne kadar süreceği hakkında bilgiler verilmiştir. Araştırmanın derinleşmesine ve zenginleşmesine katkı sağlamak amacıyla yapılan 
görüşmeler öğretmenlerin izniyle ses kayıt cihazına alınmıştır. Yapılan görüşmeler yaklaşık olarak bir saat kadar sürmüş̧ür.

Veri analizinde görüşme yoluyla elde edilen verilerin ses kayıtları çözümlenerek bilgisayar ortamına aktarılmıştır. Çözümlemeden sonra NVivo 10 Nitel Analiz Programı kullanılarak betimsel analizler yapılmıştır. Betimsel analizde görüşme sorularından oluşan maddeler sistematik ve açık biçimde düzenlenerek betimlenmiştir. Bu amaçla ilk olarak kodlar oluşturulmaktadır. Bu kodlamalar sonucunda kodlama yoğunluğu, frekans (f) ve yüzde hesapları (\%) bilgileri metin içlerinde sunulmaktadır. Öğretmenlerin görüşlerini yansıtmak amacıyla doğrudan alıntılar yapılmıştır. $\mathrm{Bu}$ alıntılar tırnak işareti içinde italik yazı ile verilmektedir. Her alıntının sonunda ise parantez içerisinde her bir öğretmene verilen bir kod, cinsiyeti ve kıdemi hakkında bilgiler yer almaktadır. Görüşmeye katılan öğretmenlere verilen kodlar “A_Kadın_11 yıl” ş̧eklindedir.

\section{BULGULAR}

A. Matematik dersi öğretim programı matematiksel süreç becerilerine ait bulgular;

Matematik dersinin kazandırmayı hedeflediği becerilerden biri ilişkilendirme becerisidir. Araştırma yapılırken bu beceri üç boyutuyla ele alınmıştır. Bunlar matematik dersinin günlük hayatla ilişkilendirilmesi, matematik dersinin diğer derslerle ilişkilendirilmesi ve matematik dersinin ders içi ilişkilendirme boyutlarıdır. Bu amaçla çalışmaya katılan öğretmenlere "Matematik dersinin günlük hayatla ilişkilendirme boyutunu dikkate aldığınızda öğrencilerin bu kavramı ne kadar kazandıklarını düşünüyorsunuz? Siz bu konuda ders işlenişlerinizde nasıl bir yol izliyorsunuz? 2005 yıl matematik dersi ögretim programında günlük hayatla iliş̧kilendirme açısından öğrencilerinizde nasıl bir değişim gözlemektesiniz? sorusu yöneltilmiştir. Bu soruda öğrencilerin matematik dersini günlük hayatla ne kadar ilişkilendirebildiklerine dair öğretmenlerin görüşlerini almak amaçlanmaktadır.

İlköğretim matematik öğretmenlerinin görüşlerine göre; matematik öğretmenleri sayılar konusunun (alış-veriş hesapları, yüzdeler, dört işlem problemleri vb. konularda) öğrencilerin günlük hayatla ilişkilendirmeyi en iyi yaptıkları öğrenme alanları arasında ( $\mathrm{f}=17 ; \% 70,8)$ olduğunu belirmektedirler Fraktallar, geometri, istatistik, koordinat sistemi gibi 8. sınıf konularını işlerken günlük hayattan örnekleri kullanabilen öğrencilerin $(\mathrm{f}=2 ; \% 8,3)$ sayısının oldukça az olduğunu belirtmişlerdir. Matematik öğretmenlerinin görüşlerine göre öğrencilerin 5 ve 6 . sinıflarda günlük hayatla ilişkilendirmeyi daha rahat kurabildikleri ancak sınıf seviyesi yükseldikçe günlük hayatla ilişki kurma becerisinde öğrencilerin zorlandıkları görüşünü $(f=10 ; \% 41,6)$ savunmaktadırlar. Matematik kitaplarının konuları günlük hayatla ilişkilendirmelerde sınıf seviyesinin üstünde olduğuna dair görüş $(\mathrm{f}=2, \% 8,3)$ belirten öğretmenler olmuştur. Bu bulgular ile ilgili olarak matematik öğretmenlerinin vermiş oldukları örnek cümleler aşağıda sunulmuştur.

“...Çok azdır diyebilirim. $O$ da niye alışverişlerde daha çok birim fiyatları hesaplamada yapabiliyorlar. Onun dışında pek fazla günlük hayatta ilişkilendirme kuramıyorlar.” (A_Kadın_11 y1l) 
“Çok değiller... İstatistik konularını anlatıyoruz onların günlük hayatla ilişkilerini kurduğunuz zaman öğrenci şaşırıyor... Mesela geometride desen oluşturma çizimleri, üçgen çizimleri var çemberleri kullanarak üçgenin temel çizimleri var. Bu çizimleri mesela derste yaptırlyorsun... Matematiksel tarihteki sürecine girdiğiniz zaman ya da bir mimarideki çizimlerine, mimarın kullandı̆̆ tekniklere ya da makine mühendislerine girdiğiniz zaman matematik bağ kurmuş oluyorsunuz." (I_Kadın_18 yıl)

"Farkındalar. Mesela koordinat sistemini... Bir savaş yapacaksın ülkeler savaş yaparken şimdi bizim uçaklarımız bir hedefi bombalayacak koordinatlarını veriyor. Işste o koordinatlar bizim bu konunun alt yapısı, o noktaya bomba atışını gösteriyorum. A noktası B noktası işte kesiştikleri nokta oraya uçak geliyor bombayı buraya atıyor. Bu şekilde anlatıldı̆̆ zaman ilişkilendirme kurabiliyorlar.” (S_Erkek_25 yil)

“Günlük hayatla program olarak otomatik ilişkilendiriyor. 5. slnıf çocukları ile çok net günlük hayatla ilişkilendirme kuruluyor... Farkındalar. Bu seviyede biz bunu nerede kullanacağız sorusu daha az geliyor.” Peki, sınıflar ilerledikçe “- Sinıflar ilerledikçe o soru artıyor.” (B_Kadın_13 yıl)

2005 yılı matematik dersi öğretim programlarımı ile birlikte matematik dersinin günlük hayatla ilişkilendirilmesi bakımından öğretmenlerin, öğrencilerinde gözlemledikleri değişimi karşılaştırmaları konusunda büyük çoğunlukla olumlu yönde gelişme olduğunu belirtmişlerdir ( $\mathrm{f}=19 ; \% 16)$. Ancak yenilen programının uygulanması sırasında herhangi bir değişiklik olmadığını $(\mathrm{f}=1 ; \% 4,1)$ belirten yalnız bir öğretmen bulunmaktadır.

Katılımcılara "2005 yılı matematik dersi ögretim programlarını matematik konuları arasında iç ilişkilendirme yaklaşımı açısından değerlendirebilir misiniz?” şeklinde soru yöneltilerek öğretmenler 2005 yılı matematik programında uygulanmaya başlayan sarmal yapı hakkında görüşlerinin toplanması amaçlanmıştır. Öğretmenler ( $\mathrm{f}=9, \% 37)$ sarmal yapının daha olumlu olduğu görüşünde birleşmektedirler. Böylelikle öğrencinin matematik konularını ilişkilendirmesinin daha kolay olduğunu ve bilgiyi sürekli tekrar etmek zorunda kalabildikleri görüşünü savunmaktadırlar. Ancak öğretmenlerden bir kısmı (f=4, \%16) ders kitaplarında bazı ilişkilendirmeler doğru yapılmadığından dolayı sıkıntı yaşadıklarını belirtmektedirler. Sarmal yapıdan vazgeçilmesi gerektiğini savunan $(\mathrm{f}=8, \% 33)$ öğretmenler de bulunmaktadır. $\mathrm{Bu}$ öğretmenler sarmal yapının konular arasında kopukluklar yarattığına vurgu yapmaktadırlar.

“Uygulamada güzel de ama bütün kazanımlar için geçerli değil. Böylelikle öğrencilerin sürekli bilgiyi tekrar etmesini sağllyorsunuz o anlamda iyi...” (B_Kadın_13 y1l)

"Sarmal bir yapıda olması daha iyi. Bunun bence öğretmenlere bırakılması gerekiyor. Çünkü o anda siz sınıfin durumuna ve kendi işleyişinize göre o sarmal yapıyı oluşturuyorsunuz. Ancak 
ögretmenlere sırasıyla kazanımları kazandırılmış bir kitap verirseniz; öğretmen o kitabı işler bitirir. Ama o kitabı işlerken sarmal yapıyı öğretmen koysa çok güzel olur...” (M_Erkek_20 yıl)

"Sarmal yapı daha iyi. Birbirleriyle alakalı konuların bir arada işlenmesi mantıklı, çocuklarda çă̆rışım yapıyor, hatırlıyorlar.” (A_Kadın_11 yıl)

"Öğrenciler de velilerde ondan çok memnun değiller. Veliler çok yavaş yavaş alışıyorlar sisteme ve biz daha da karma karışığız kitap başka biz başka olduğumuz için daha çok kafaları karışıyor. Şimdi ne işleyeceğiz diye çocuklara bilgi vermek zorundayız, bilmiyorlar sırada ne var." (O_Kadın_20 y1l)

Matematik öğretmenlerine “Öğrencileriniz matematik dersini diğer derslerle ilişkilendirebiliyorlar mı? Bu konu hakkındaki görüşünüzü açıklar mısınız? 2005 yılı matematik programları arasında nasıl bir değişim gözlemlemektesiniz?” sorusu yöneltilmiştir. Bu sorunun amacı ögrencilerin matematik dersini diğer derslerle ne kadar ilişkilendirebildiklerine dair öğretmenlerin görüşlerini almak amaçlanmaktadır. İlköğretim matematik öğretmenlerinin görüşlerine göre öğrenciler matematik dersinin diğer derslerle ilişkilendirildiğinin farkında oldukları yönünde olmuştur ( $\mathrm{f}=7$; \%29,1). Bazı öğretmenler ise öğrencilerin matematiğin diğer derslerle ilişkilendirildiğinin farkında olmadığ1 yönünde görüş $(\mathrm{f}=12 ; \% 50)$ belirtmiştir. $\mathrm{Bu}$ şekilde görüş belirten öğretmenlere göre ögrencilerin matematiği diğer derslere aktarmakta zorlandıklarını belirtmektedirler.

“Kendileri söylüyor mesela biz bu konuyu önceden gördük. Sosyal dersinde ölçek konusunda nasıl işlediklerini anlatıyorlar. Mutlaka ilişkilendiriyorlar... Görsel sanatlarda falan çizimler çok işlerine yarıyor, çünkü hatırlıyor çocuk mutlaka kullanıyor.” (F_Erkek_14 yıl)

“Gerekli olduğunun farkındalar. Zaten iş birliği yapıyoruz fen bilgisi ögretmenleriyle, sosyal bilgiler, coğrafya gibi...” (C_Erkek_13 yıl)

“Bu konuda sıkıntı var. Fen ögretmeni geliyor diyor ki, çocuk halen fenle matematiği iki ayrı ders olarak görüyor. Matematikte öğrendiği yüzdeyi, 5. sinıfta ögrendi 6. sinıfta fen dersinde uygularken onu oraya aktaramıyor. Mesela bir orantı, fende kullanırken sanki onu matematikte kullandım bitti gibi düşünüyor..." (L_Kadın_18 yı1)

Matematik öğretmenlerinin, öğrencilerin iletişim becerilerinin gelişimlerine yönelik olarak görüşleri şu şekildedir: İletişim becerisi konusunda az sayıda öğretmenden yeterli bilgi ( $\mathrm{f}=5, \% 20)$ alınmıştır. $\mathrm{Bu}$ öğretmenler iletişim becerisi konusunda derslerinde yaptıkları etkinliklerden sonra öğrencilerin kendi düşüncelerini açıklamalarına firsat vererek bu becerinin gelişmesi için çaba sarf ettikleri yönünde görüş belirtmişlerdir.

"İletişim becerilerini de ben sinıfta yaptırdı̆̆ım etkinliklerden sonra çocuklardan kendi düşüncelerini açıklamaların istiyorum. Bu şekilde iletişim becerisini gelişstirmeye çalışıyorsunuz, ...” (I_Kadın_18 yıl) 
Matematik öğretmenlerine "2005 yılı matematik dersi ögretim programlarının ögrrencilerin matematiksel akıl yürütme (muhakeme) becerisinin gelişimini nasıl etkilediğini düşünüyorsunuz. Açıklar mısınız? şeklinde soru yöneltilerek öğretmenlerden akıl yürütme becerisinin kazanılması konusunda görüşleri alınmak istenmektedir. $\mathrm{Bu}$ soruya verilen cevapların incelenmesi sonrasında sadece ( $\mathrm{f}=5, \% 20$ ) beş öğretmenin yeterli görüş bildirdiği görülmektedir. Bu öğretmenler matematiğe eğilimi olan öğrenciler için değişimin olumlu katkı sağladığını belirtmişlerdir.

“Akll yürütme becerisini sayllar konusunda çok ağıllıklı olarak görüyoruz. Tahmin de geometri de istatistikte de var akıl yürütme... Ancak çocuklarda eski bildikleriyle yeni bildiklerini bağlama, birleştirme olayı olmadiğı için, sadece çocuk bilgiyi öğreniyor ezberliyor; onu hafizaya alıyor. Bildiğini akıl yürüterek diğer bir kazanımla bağlantıl yapayım ya da orada öğrendiğim bilgiyi buraya aktarayım gibi olmuyor.”(I_Kadın_18 yıl)

Matematik öğretmenlerinin "Problem çözme basamakları (problemi anlama, plan yapma, planı uygulama, çözümün doğruluğunu kontrol etme, çözülen probleme benzer problem kurma) nelerdir? Derslerinizde problem çözme basamaklarını nasıl kazandırıyorsunuz? Açıklar mısınız? 2005 yılı matematik dersi ögretim programı öğrencilerin problem çözme süreçlerine olan katkısını açıklar mısınız?" şeklinde soru yöneltilerek öğretmenlerin problem çözme basamaklarını derslerinde nasıl işlediklerine yönelik bilgi toplamak ayrıca öğrencilerin problem çözme becerilerinin gelişimi hakkında gözlemlerini incelemek amaçlanmıştır.

Öğretmenlerin görüşlerinden elde edilen verilerin bulguları üç farklı başlık altında toplanmıştır. Bu başlıklar;

- Problem kurma çalışmalarını derslerinde etkili şekilde işleyebilme hakkındaki görüşleri,

- Problem çözme basamaklarını uygulama aşamasında karşılaştıkları sorunlar,

- Problem çözerken öğrencilerin farklı çözüm stratejileri üretebilmelerine yönelik görüşleri şeklindedir.

Matematik öğretmenlerinin öğrencilerine problem çözme basamaklarını nasıl kazandırdıklarına dair görüşleri incelendiğinde; problem çözme basamaklarından problemi anlama, plan yapma, planı uygulama ve çözümün doğruluğunu kontrol etme aşamalarını tek tek işlediklerini belirten öğretmenlerin oranı $(\mathrm{f}=10 ; \% 37,5)$ olarak belirlenmiştir. Problem çözme basamaklarını derslerinde zaman zaman uyguladıklarını belirten öğretmenlerin oranı $(\mathrm{f}=11 ; \% 74,3)$ ve problem çözme basamaklarını derslerinde uygulamadıklarını belirten öğretmenler ise $(\mathrm{f}=2 ; \% 17,2)$ olarak belirlenmiştir.

Problem çözme basamaklarını derslerinde uyguladıklarını belirten öğretmenler görüşme sırasında bu çalışmaları yaparken karşılaştıkları sorunlar hakkında detaylı bilgiler toplanmıştır. Öğretmenlerin karşılaşıtıları sorunlardan biri; problem çözme basamaklarının öğrencilere hikâye gibi 
geldiğinden bu aşamaları yapmak istemedikleri yönünde olmuştur ( $\mathrm{f}=1 ; \% 4,3)$. Öğretmenlerin bazıları ise öğrencilerin çözüme odaklı olduklarını ve bu yüzden öğrencilerin plan yapma aşamasını zihinlerinde yaparak direkt çözüme geçtiklerini $(\mathrm{f}=3 ; \% 26,5)$ belirtmişlerdir. Bir öğretmenin görüşü ise öğrencilerin bilgisini gösterme odaklı olduklarından bu aşamaları atladıklarını $(\mathrm{f}=1 ; \% 4,2)$ belirtmiştir. Öğrencilerin ilkokuldan gelen alışkanlıkları bırakamadıklarını savunan diğer öğretmen görüşü ise sınıf öğretmenlerinin ezbere dayalı soru çözümü yaptıklarından dolayı problem çözme basamaklarını işlerken zorlandıkları şeklindedir. Bu şekilde soru çözmeye çalışan öğrenciler ortaokula geçtiklerinde yeni stratejilerle uğraşmadıklarını $(\mathrm{f}=2 ; \% 16,4)$ belirtmişlerdir.

"Tabi plan yapıyorlar. Yaptırıyorum daha doğrusu. Ne isteniyor problemde, verilenleri yazdırıyorum. Verilenler, istenilen, çözüm yolu yazdırıyorum. Buna göre adım adım yapabiliyorlar." (C_Erkek_13 y1l)

“...yazllı çok uzun sürüyor. Ama sözel olarak diyorum çocuklar problemi çözmekte birkaç aşama vardır diye önce anlamak, sonra farklı şekilde plan yapmak, çözmek, kontrol etmek, bu aşamaları sözel olarak hep söyledim... Defterlerine ama yazdırmadım.” (H_Kadın_17 y11)

“Çocuklar sinav merkezli olduğu için şu an sadece sonuca odaklanıyorlar. Sorunun çözümüne değil de sonuca bakiyor." (V_Erkek_32 y1l)

“...Planı kafasında yapıyor genelde yapmıyor. Hemen çözüme geçmeye çalışıyorlar. Hatta soruyu tam anlamadan çözüme geçiyorlar. Çocuklarda böyle bir şey var.”(R_Kadın_22 yıl)

"Niye uzatıyorsunuz işlemi bu kadar diyorlar. Çünkü aşamaları neden yapması gerektiğinin de farkında değil. Direk sonuca odaklanıyorlar.”(T_Kadın_25 yıl)

"Problem çözme becerilerinin ülkemizde en çok sılkıntı yaşanılan yer olarak düşünüyorum ve ben bununla ilgili en büyük hatanın sınıf ögretmenlerinde olduğunu düşünüyorum. Soruları çocuklarımıza verip ezber yaptırarak bu böyle çözülür diyorlar. Böyle bir problem var, kuralı budur üçe bölüp beşle çarpacaksınız. Veya buradan hep tersten gideriz işte bunu çıkartırız bunu topları diye çocuk düşünmeden ezber yöntemine gittiği için problem kurmayı bilmiyorlar.” (S_Erkek_25 yıl)

Problem çözme basamaklarından biri olan problem kurma aşmasına yönelik olarak katılımcıların görüşleri; problem kurma çalışmalarını derslerinde etkili şekilde işlediklerini belirten öğretmenlerin sayısı oldukça az $(\mathrm{f}=3 ; \% 17,2)$ ve problem kurma çalışmalarını derslerinde etkili şekilde işlemediklerini belirten öğretmenlerin oranı $(\mathrm{f}=12 ; \% 60,2)$ olarak belirlenmiştir. Problem kurma çalışmalarını etkili şekilde işleyemeyen öğretmenler görüşlerinde; öğrencilerinin problem kurma çalışmalarını yapmak istemedikleri şeklinde dönüt aldıklarını bu durumda öğrencilerin test kitaplarında ve ulusal sınavlarda bu türden çalışmalarla karşılaşmadıklarından kaynaklandığını belirtmişlerdir. Problem kurma çalışmalarını etkili şekilde işlediklerini belirten öğretmenler ise öğrencilerin problem kurma çalışmalarını yapabildiklerini belirtmişler ancak öğretmenler, 
öğrencilerine yorum kazandırma ve probleme farklı bakış açısı sağlama konusunda kendilerinin yetersiz kaldıkları görüşünü belirtmişlerdir.

"Kurabiliyorlar ama ders kitabında öyle problem soruları oluyor ki onları açıkçası geçiyorum. Çünkü zaman kaybı gibi geliyor. Ama illa şunla ilgili problem kurun demedim... Daha doğrusu çok işlenmiyor kendi adıma söyleyeyim.” (L_Erkek_19 yı1)

“Çünkü neden test kitaplarında yok, sinavda çıkmayacak.” (F_Erkek_14 yıl)

Öğretmenlerin problem çözme basamaklarını derslerinde öğrencilere nasıl kazandırdıklarına dair görüşler alınırken öğrencilerin farklı çözüm stratejileri üretme konusundaki becerileri hakkındaki görüşleri de ortaya çıkmıştır. Öğretmenlerin bu konu hakkındaki görüşleri ise öğrencilerin farklı çözüm yöntemleri üretebildikleri $(\mathrm{f}=8 ; \% 33,3)$ yönünde olmuştur. Ancak bu öğretmenlerin bu konudaki ortak görüşü matematik yeteneğine sahip olan çocuklarda probleme farklı bir bakış açısı getirebildikleri yönünde ( $f=7 ; \% 9,1)$ olmuştur. Diğer öğretmenler ise öğrencilerin farklı çözüm yolları üretme konusunda yetersiz kaldıklarını ( $\mathrm{f}=11, \% 45,8)$ belirtmişlerdir.

“Farklı yol üreten var. Ama çocuğun matematik becerisine bağlı iyi çocuk üretiyor. Ama belli bir seviye üstündeki çocuklar yapıyor.” (K_Erkek_18 y1l)

"Farklı çözüm yolları üretebiliyorlar. Bunu programa bağlamamak lazım ama eskiden de oluyordu, problemin çözümü iki üç yoldan yapılıyordu. Program değissti böyle oldu dememek lazım.” (G_Erkek_16 y1l)

“...Bildikleri yoldan farklı bir strateji gösterdiğin zaman çok uzun yol diyorlar ya da karışık. Problem çözmenin birtakım stratejileri var biliyorsunuz. Örüntü bulma gibi bunlar onlara angarya veya gereksiz geliyor." (V_Erkek_33 yıl)

Matematik öğretmenlerine "Problem çözme becerisini kazanma konusunda 2005 yılı matematik programları dikkate alındı̆̆ında öğrencilerinizde nasıl bir gelişme gözlüyorsunuz? Açıklayabilir misiniz?” şeklinde problem çözme süreci ile ilgili görüşleri incelenmiştir. Problem çözme becerilerini kazanma konusunda 2005 yılı matematik dersi öğretim programı ile birlikte olumlu yönde gelişme olduğunu belirten öğretmenler $(\mathrm{f}=5 ; \% 20,8)$ oranındadır. Bu öğretmenler yenilenen programın modellemeler ve örüntüler yoluyla problem çözme becerilerine yeni bir bakış açısı kazandırdığını belirtmiştir. Ancak problem çözme becerilerini kazanma yönünde eski programlara nazaran bir değişiklik olmadığını belirten öğretmenlerin ( $f=17 ; \% 70,8)$ olduğu tespit edilmiştir.

“...belki biraz... matematiği görmeye başladık. Bu olabilir tek faydası, yani başka bir faydasını ben bilemiyorum." (P_Kadın_23 y11)

B. Öğretim yaklaşımlarına ait bulgular;

“Etkinlik nedir? Etkinlik temelli öğretimi derslerinizde nasıl uyguladı̆̆ınızı açıklar mısınız? Öğrencileriniz etkinlik yaparken somut deneyimlerini matematiksel olarak ifade edebildiklerinin 
farkındalar mı? Bu konu hakkındaki görüşleriniz nelerdir?" şeklinde matematiksel kavramları keşfetmeye yönlendiren etkinlikler üzerine öğretmenlerin etkinliği nasıl tanımladıkları, öğrenme öğretme sürecinde matematiksel kavramları öğrencilerine kazandırma boyutunda ders işlenişlerinde etkinlik temelli öğretimi ne kadar kullanabildiklerini sorgulamak amaçlanmıştır. Görüşmelere katılan öğretmenlerden etkinlikleri derslerinde etkin olarak kullanan, çok fazla kullanamadığını belirten veya hiç kullanmadığ1 yönünde görüş bildiren öğretmenlerin hepsi etkinlik temelli öğretimi öğrencinin matematiği algılamasına olumlu katkısı olduğu yönünde görüş belirtmişlerdir. Ancak derslerinde etkinlikleri uygulama aşamasına geldiğinde durum oldukça farklı sonuçları göstermektedir. Etkinliği derslerinde çok sık kullandıklarını belirten öğretmenlerin sayısının oldukça az olduğu ortaya çıkmıştır $(\mathrm{f}=3, \% 12,5)$. Bu öğretmenlerin ortak görüşü etkinliklerin sadece 5 ve 6 . sinıftaki derslerinde verimli olarak işlenebildiği yönündedir. Sınıf seviyesi yükseldikçe özellikle 8. sınıflarda etkinliklerin yapılamadığını hemen hemen tüm öğretmenler özellikle belirtmişlerdir ( $\mathrm{f}=15, \% 62,5)$. Etkinlik temelli ders işlemeye gayret gösterdiklerini söyleyen öğretmenlerin önemli sıkıntısı öğrencilerin materyalleri ilkokuldan tanımadan gelmiş olmalarının kendilerine dezavantaj olduğunu belirtmeleridir $(\mathrm{f}=2, \% 8,3)$. Etkinlikleri çok fazla kullanmadıklarını belirten öğretmenlerin sayısının az olmadığı görülmektedir ( $\mathrm{f}=10, \% 41,6) . \mathrm{Bu}$ öğretmenler etkinlikleri derslerinde kullanmadıklarını söyleyerek ders kitabındaki etkinlikleri sadece bahsederek üzerinden geçtiklerini veya eve ödev olarak verdiklerini söylemişlerdir. Etkinlikleri hiç kullanmadıklarını belirten öğretmenler de olmuştur ( $\mathrm{f}=7, \% 29,1)$. Bu öğretmenler zaman, sınıfların kalabalık olması, programların yoğunluğundan, lise yerleştirme sınavlarına hazırlanma kaygılarının etkinlikleri uygulamayı göz ardı etmelerine sebep olarak göstermektedirler.

“Kullanabildiğiniz konularda etkisini görebiliyorsunuz. Etkinlik sadece oyun değil matematikte, görsel kavramları çocuklara gösterdiğimiz için mesela ufacık bir prizmayla geldiğiniz zaman bile bir etkinlik. Hem oyun oynadı̆̆ınız için dikkatli dinliyorlar hem de gördükleri, yaşadıkları için konuyu daha iyi algılayabiliyorlar. Dersle ilgili kazanımla ilgili bir şey vermeseniz bile dikkatlerini çekmiş oluyorsunuz ve ne demek istediğinizi anlatmış oluyorsunuz. Ama tabi her konuda kullanamıyorsunuz." (H_Kadın_17 yıl)

"Etkinlik yaptırdı̆̆ım zaman faydası şu oluyor çocuk gene anlıyor. Anlıyor dediğim en iyisi de katıllyor en kötüsü de yorum yapabiliyor olaya." (I_Kadın_18 yıl)

Matematik öğretmenlerine "Öğrenci merkezli yaklaşım ve öğretmen merkezli yaklaşım hakkında bilgi verir misiniz? Bu yaklaşımlar sizin ders işlenişlerinize nasıl yansımakta? Karşılaştığınız kolaylık ve güçlükler nelerdir? Açılayabilir misiniz?” ş̧eklindeki soru öğretmenlere yöneltilerek öğrenci merkezli ve öğretmen merkezli yaklaşım olarak nitelendirilen programlar hakkında öğretmenlerin görüşlerini alarak ders işlenişlerinde hangi yaklaşımı kullandıklarını öğrenmek amaçlanmaktadır. 
Genel olarak araştırmaya katılan öğretmenler eski matematik programlarını öğretmen merkezli olduğunu belirtenlerin oranı çoğunluktadır ( $\mathrm{f}=20, \% 83$ ). 2005 yılı yayınlanan matematik programının öğrenci merkezli olduğunun söylenmesine rağmen iş yükünün öğretmen üzerinde olduğunu vurgulanmaktadır ( $\mathrm{f}=19, \% 79)$. Bu programı tam olarak öğrenciyi merkeze alacak şekilde işlendiğini belirten öğretmen olmamıştır. Derslerini öğrenci merkezli olarak yürütmeye çalıştığını belirten az sayıda öğretmen olmuştur $(\mathrm{f}=2, \% 8)$. Programların uygulanması aşamasında ders işlenişlerinde nasıl bir değişim olduğuna dair görüşlerinde ise klasik şekilde ders işlemeye devam ettiklerini belirten öğretmen görüşleri az değildir ( $\mathrm{f}=14, \% 58)$. Diğer öğretmenler ise yeni programı uygulamaya çalıştıklarını ancak zamanla klasik yönteme döndüklerini belirtmişlerdir ( $\mathrm{f}=4, \% 16)$.

"Görsel ve somut materyalleri derslerinizde kullanma sıklı̆̆ını hakkında bilgi verir misiniz? Neden kullanıp neden kullanmadı̆̆ınız hakkında bilgi verebilir misiniz? Bu konuda 2005 öncesi matematik programlarına göre nasıl bir değişiklik oldu? şeklinde soru yöneltilerek öğretmenlerin görsel ve somut materyalleri derslerinde hangi sıklıkta kullandıklarına dair bilgileri öğrenmek amaçlanmıştır. Görsel ve somut materyalleri derslerinde çok sık kullandığını belirten sadece (f=1, \%4) öğretmen olmuştur. Öğretmenlerin büyük kısmı çok fazla derslerinde ( $f=16, \% 66)$ görsel ve somut materyalleri kullanmadıkları yönünde görüş belirtmiştir. Bazı öğretmenler ise kullanmadıklarını ( $\mathrm{f}=7$, \%33) belirtmişlerdir.

Ölçme ve değerlendirme yaklaşımlarına ait bulgular;

"Kullandiğını ölçme ve değerlendirme araçları hakkında bilgi verir misiniz? Bu ölçme araçlarını ne kadar sıklıkta kullanıyorsunuz?

a) Farklı türde sorular (çoktan seçmeli sorular, doğru-yanlış soruları, eşleştirmeli sorular, açık uçlu sorular, boşluk doldurmalı sorular, klasik yazılı sınavlar)

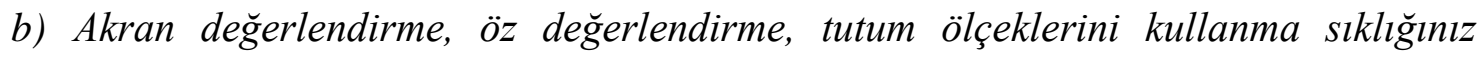
nedir?" soruları yöneltilerek öğretmenlerin matematik derslerinde kullandıkları ölçme araçlarının sıklıkları derinlemesine incelenmeye çalışılmıştır. Yapılan analiz sonucunda ilköğretim matematik öğretmenlerinin derslerinde kullandıkları ölçme araçlarının türleri belirlenerek kategoriler halinde Tablo 2'de sunulmuştur.

Tablo 2. Öğretmenlerin Kullandığı Ölçme Araçlarının Frekans ve Yüzde Değerleri

\begin{tabular}{llll}
\hline Ölçme Araçları & Kategoriler & $\mathrm{n}$ & $\%$ \\
\hline Çoktan seçmeli & Kullandığına dair görüşler & 24 & 100 \\
& Kullanmadığına dair görüşler & 0 & 0 \\
\hline Doğru yanlış & Kullandığına dair görüşler & 18 & 75 \\
& Kullanmadığına dair görüşler & 4 & 16,6 \\
\hline Eşleştirmeli & Kullandığına dair görüşler & 5 & 20,8 \\
& Kullanmadığına dair görüşler & 12 & 50 \\
\hline
\end{tabular}




\begin{tabular}{llll}
\hline Açık uçlu & Kullandığına dair görüşler & 2 & 8,3 \\
& Kullanmadığına dair görüşler & 9 & 37,5 \\
\hline Boşluk doldurmalı & Kullandığına dair görüşler & 3 & 12,5 \\
& Kullanmadığına dair görüşler & 19 & 79,1 \\
\hline Klasik yazılı sınavlar & Kullandığına dair görüşler & 15 & 62,5 \\
& Kullanmadığına dair görüşler & 7 & 29,1 \\
\hline
\end{tabular}

Öğretmenlerle yapılan görüşmeler sonucunda farklı türdeki ölçme araçlarını derslerinde hem kullandıkları hem de kullanmadıklarına dair bazı görüşler elde edilmiştir. Matematik öğretmenleri çoktan seçmeli sorular ( $\mathrm{f}=24 ; \% 100)$, doğru yanlış soruları $(\mathrm{f}=18 ; \% 75)$, eşleştirme sorular $(\mathrm{f}=5$; $\% 20,8)$, açık uçlu sorular $(\mathrm{f}=2 ; \% 8,3)$, boşluk doldurmalı sorular $(\mathrm{f}=3 ; \% 12,5)$ ve klasik yazılı sınavlar $(\mathrm{f}=15 ; \% 62,5)$ oranında derslerinde kullandıkları anlaşılmaktadır.

Öğretmenlerin sınavlarında ölçme aracı olarak genellikle çoktan seçmeli sorulara ağırlık vermektedirler. Klasik yazılı sınavları ölçme araçlarını mutlaka kullandıkları verdikleri cevaplardan anlaşı1maktadır. Sadece klasik yazılı sınavları ölçme aracı olarak kullanan ( $f=15 ; \% 62,5)$ öğretmen olduğu alınan cevaplarla anlaşılmıştır. Diğer taraftan bazı matematik öğretmenlerinin görüşleri incelendiğinde doğru yanlış soruları $(\mathrm{f}=4 ; \% 16,6)$, eşleştirme soruları $(\mathrm{f}=12, \% 50)$, açık uçlu sorular ( $\mathrm{f}=9 ; \% 37,5)$, boşluk doldurmalı sorular $(\mathrm{f}=19 ; \% 79,1)$, klasik yazılı sınavları $(\mathrm{f}=7, \% 29,1)$ oranında derslerinde kullanmadıkları belirlenmiştir. Ancak öğretmenlerin programda istenen açık uçlu soruları kullanmayı tercih etmedikleri göze çarpan noktalardan biridir. Eşleştirmeli, doğru yanlış ve boşluk doldurmalı soruları ise matematik öğretmenleri çoğunlukla tercih etmemektedirler.

Akran değerlendirme, öz değerlendirme, tutum ölçeklerini kullanma sıklıklarına verdikleri cevapları dinlediğimiz zaman öğretmenlerin bu formları doldurmadıkları belirtmişlerdir. Diğer öğretmenler ise bu formları doldurmayı iş yükü olarak görmekte ve faydalı olduğuna inanmadıklarını söylemişlerdir.

\section{TARTIŞMA VE SONUÇLAR}

$\mathrm{Bu}$ çalışmada, matematik öğretmenlerinin matematik dersi öğretim programının kazandırmayı hedeflediği matematiksel süreç becerileri, öğretim yaklaşımları ve ölçme değerlendirme boyutlarına ilişkin olarak görüşlerini incelemek amaçlanmıştır. Bu bağlamda 24 matematik öğretmeni ile yarı yapılandırılmış görüşmeler yapılarak araştırma ile ilgili görüşleri alınmıştır.

Günlük hayatla ilişkilendirme becerisine ilişkin öğretmen görüşleri incelendiğginde öğrencilerin 5 ve 6. sınıflarda günlük hayatla ilişkilendirmeyi daha rahat sağladıklarını ancak sınıf seviyesi yükseldikçe yani 7 ve 8 . sınıflarda bu beceriyi ilişkilendirmekte zorlandıklarını belirtmektedirler. Bunun önemli sebeplerinden biri matematiğin soyut bir kavram olmasından kaynaklanıyor olabilir. Umay (1996), küçük yaşlarda matematik öğretimine somut deneyimler ile başlansa da zihinsel bir sistem olarak matematiğin soyut düşünmeye yönelik olduğunu belirtmektedir. Başlangıç seviyesi için 
simgeler kullanılmadan matematik yapılmaktadır. Ancak simgeleme soyutlamayı kolaylaştırmakta ve matematik için vazgeçilmez olmaktadır. 6-8. sınıflar için matematik dersi program kitabında tüm kazanımlar için etkinlik örnekleri verilmekte ve bu her sınıf için uygun araç gereç yardımıyla kazanımların somutlaştırılmış örnekleri yer almaktadır. Matematik öğretmenlerinin ise ders kitaplarında matematiğin günlük hayatla ilişkilendirme örneklerine yeterince yer verilmediği şeklinde yorumları dikkate alınması gereken önemli noktalardan biridir.

Albayrak (1996), eski programın gerçekleşmeme nedenleri arasında bazı amaçların günlük hayatla ilişkilendirmelerinin az olması olduğunu vurgulamıştır. Budak ve Okur (2012), ilköğretim matematik öğretmenleri ile yaptığı çalışmasında 2005 yılı 6-8. sınıf matematik programının güçlü yönlerinden birinin güncel olması ve konuların günlük hayatla ilişkilendirilmiş şekilde sunulmuş olması olduğunu vurgulamaktalar. Dağlar (2008), 6. sınıf matematik programını matematiği günlük yaşamla kullanılması açısından yeterli görmektedir. Ören (2010), matematik 8. sınıf programının günlük hayatla iyi ilişkilendirildiği sonucuna ulaşmıştır. Ancak yapılan bu çalışmada ise matematik öğretmenlerinin görüşleri 8. sınıf konuları arasında yer alan trigonometri, fraktal gibi öğrenme alanlarına ait kazanımların günlük hayatla ilişkilendirmede zorlandıklarını söylemektedirler. Matematiğin günlük hayatla ilişkilendirilmesinde sınıf ortamında ve öğretmen merkezli bir eğitim sisteminde zorluk yaşanması oldukça doğaldır. Bu yüzden birçok kavramın anlamlı hale gelmesi için uygulama alanlarının çeşitlendirilmesi ve farklı öğrenme sitilleri ile desteklenmesi gerekmektedir (Bransford ve Brown, 1999). Bu çalışmada ise öğretmenler, öğrencilerin matematiği günlük hayatla ilişkilendirebilmeleri için ders kitaplarının öğrencilerin matematik ve günlük yaşam arasındaki bağı kuracak nitelikte olmasını istemektedirler.

Diğer derslerle ilişkilendirme becerisine ilişkin öğretmen görüşleri incelendiğinde matematik öğretmenlerin yarısı öğrencilerin matematiği diğer derslerle ilişkilendirme konusunda yetersiz olduğu şeklinde görüş belirtmişlerdir. Bu şekilde düşünen öğretmenler öğrencilerin matematiği diğer derslere aktarmakta zorlandıklarını belirtmektedirler. Bulut (2010), 8. sınıf öğrencilerin fen ve matematik entegrasyonunun etkinliğini araştırdığı çalışmasında, fen ve matematik programlarının etkili şekilde uygulayabilmesi için hem fen hem de matematik programının içerik ve becerilerine öğretmenlerin hâkim olması gerektiğini söylemektedir. Öğretmenler öğrencilerin matematiğin diğer derslerde de işlendiğinin farkında olduklarını söylerken uygulama aşamasında zorluk çektiklerini belirtmektedirler. Mesela, 5. sınıfta öğrendiği yüzde kavramını 6. sınıftaki fen bilgisi dersindeki konulara aktartmakta zorlandıkları gibi.

Ders içi ilişkilendirme becerisine ilişkin öğretmen görüşleri incelendiğinde matematik öğretmenlerin \%37 lik kısmı yenilenen programla birlikte ders içi ilişkilendirmenin yani sarmal yapının olumlu olduğunu söylerken \%33 lük kısım ise olumsuz olduğu yönünde görüş belirtmişlerdir. Sarmal şekilde ders işlenişin olumlu olduğuna dair görüş bildiren öğretmenler öğrencinin öğrenemediği bir konuyu telafi edebilmesi için tekrar olanak elde etmesi bilginin sürekli tekrar 
edilmesi, konular arasındaki bağlantının sürekli kurulması açısından olumlu olduğunu söylemektedirler. Avcu ve Yenilmez (2011), çalışmalarında öğretmenlerin yenilenen program yaklaşımının gereği sarmal yapı hakkında bilgilerinin eksik olduğunu söylemektedirler. Bu çalışma ise öğretmenlerin çoğunluğunun ders içi ilişkilendirmede sıkıntı yaşadıklarını göstermektedir.

Matematik programlarının öğrencilerin problem çözme becerilerinin gelişimleri üzerindeki değişimi öğretmen görüşlerine dayanarak yorumlamak için; öğretmenler problem çözme basamaklarını derslerinde nasıl işledikleri sorulmuştur. Araştırmaya katılan öğretmenlerin \%37,5 problem çözme basamaklarını derslerinde işlediklerini belirtirken $\% 74,3$ problem çözme basamaklarını zaman zaman uyguladıklarını ve \%17,2 problem çözme basamaklarını uygulamadıklarını belirtmiştir. Zaman zaman uyguladıklarını belirten öğretmenler; genellikle uyguladığım zamanlar oldu, çok değil şeklinde cevaplar vermiştir. Öğretmenlerin problem çözme basamaklarını uygulama aşamasında karşılaştıkları sorunlara gelince; bu aşamaların öğrencilere hikâye gibi geldiğinden gereksiz olarak gördükleri, öğrencilerin çözüme odaklı olduklarını plan yapma aşamasını zihinlerinde yaparak direkt çözüme geçtiklerini, ilkokuldan gelen alışkanlıklardan dolayı ezbere çözüm yapmalarını farklı stratejiler üzerinde durmamaları şeklinde görüşler yer almaktadır. Fakat 2005 yılı matematik programının problem çözme becerilerine farklı stratejiler ile yeni bakış açısı kazandırması bakımından olumlu bulmalarına rağmen genel olarak öğretmenlerin problem çözme basamaklarını uygulamadıkları sonucuna ulaşılmıştır.

Öğrencilerin farklı çözüm stratejileri üretebilme üzerine görüşleri ise genellikle matematiksel yeteneğe sahip öğrencilerin farklı çözüm stratejisi üretme yönünden yeterli oldukları, diğer öğrencilerin ise bu konuda yetersiz kaldıklarını belirtmişlerdir. Sonuç olarak öğretmenlerin problem çözme basamaklarını (problemi anlama, plan yapma, planı uygulama, çözümün doğruluğunu kontrol etme) derslerinde işlemedikleri şeklinde yorumlanabilir. Yayan (2010), 6. sınıf öğrencileri ile yaptığ problem çözme testi ve anketleri sonucunda öğrencilerin genel olarak problem çözme beceri testinden düşük performans sergilediklerini söylemektedir. Dört aşamalı problem çözme yapısı içerisinde ise öğrencilerin problemi anlama sürecinin en iyi, çözümü kontrol etme ve değerlendirme aşmalarının en kötü performans sergilendikleri bölümler olduğunu vurgulamaktadır. Bu çalışmaya benzer sonuç Yazıcı (2009), 6. sınıf programını değerlendirmesini yaptığı çalışmasında öğrencilerle çalıştığı tüm gruplarda çözümün kontrolü aşamasında 0,50 civarında ya da daha düşük puanlar elde ettiği yani bu aşamanın yeterli öğrenme düzeyine ulaşmadığını belirtmektedir. Alan (2009), 5. sınıf öğrencilerinin problem çözme süreçlerini araştırdığı çalışmasında bölge ve çevre faktörünün etkisiyle öğrencilerin problemi anlama ve plan yapma aşamalarını uygulamadıklarını söylemektedir. Problemin çözümünün uygulanması aşamasına bakıldığında öğrencilerin yarısından fazlasının bu aşamayı doğru biçimde sonuçlandırdığını söylemektedir. Yapılan bu araştırmada, öğretmenlerin derslerinde problem çözme aşamalarını yeteri kadar işlemedikleri sonucuna ulaşılabilir. 
NCTM (2000), matematik eğitimi öğrencileri düşünmeye sevk ettiğinden problem kurmanın önemli bir yapı taşı olduğunu savunmaktadır. Problem koşulları değiştirilerek yeni problemler kurulmasına olanak sağlanması gerektiğini vurgulamaktadır. Ancak öğretmenler problem kurma çalışmalarına derslerinde yeterince yer vermediklerini tespit edilmiştir. Açıkça çalışmaya katılan öğretmenlerin \%60’1 problem kurma çalışmasını derslerinde işlemedikleri belirtmişlerdir. Akay (2006), problem kurma yaklaşımı ile yapılan matematik eğitimin öğrencilerin akademik başarılarında ve problem çözme becerileri üzerinde pozitif bir etkisi olduğunu belirtirken yaratıcılıkları üzerinde ise bu olumlu etkinin olmadığını söylemektedir. Yeni problem oluşturma ve problem durumlarının formüle edebilmeleri açısından öğrencilere firsatlar verilmesi gerekirken problem kurma çalışmaları problem çözme başarısını artırmaktadır (English ve Halford, 2012).

Öğretmenler problem kurma çalışmalarına ulusal sınavlarda yer verilmediği, test kitaplarında yeri olmadığı, ders kitaplarında yeterince yer verilmemesi, dershanelerde işlenmemesi, öğrencilere angarya gelmesi ve problem kurma çalışmasının zaman kaybı olarak görülmesi nedenlerinden dolayı işlemediklerini belirtmişlerdir. Araştırmaya katılan öğretmenlerden üç kişi problem kurma çalışmasını derslerinde işlediklerini belirtmelerine rağmen yorum kazandırma konusunda kendilerini yetersiz olarak görmektedirler. Matematik programın temel becerisi olan problem çözme becerinin temel amaçlarında biri olan problem kurma matematik derslerinde işlenmediği şeklinde yorumlanabilir. Problem çözme ile problem kurma arasındaki birbirini destekleyen ilişkiyi ortaya koydukları çalışmalarında Silver ve Cai (1996), problem kurma çalışmaları sayesinde öğrencilerin daha iyi problem çözücü olduklarını tespit etmişlerdir. Benzer şekilde Dickerson (1999), problem kurma çalışmaları yaptığı 8. sınıf öğrencilerinin matematik başarılarında diğer öğrencilere göre olumlu artış olduğunu söylemiştir. Bu çalışmalara kısmen farklı bir yaklaşımı olan Turhan (2011), 6. sınıf öğrencileri ile problem kurma yaklaşımı ile gerçekleştirilen matematik eğitimin problem kurma becerisini arttırdığını ancak problem çözme becerisi üzerine etkisi olmadığını söylemektedir. Öğretmenler derslerinde problem kurma çalışmalarına yeterince yer vermemeleri bu kazanımlardan haberdar olmadıklarını göstermektedir.

Birgin (2010), ölçme ve değerlendirme sürecinde karşılaşılan tüm sorun ve zorlukların öğretmenleri geleneksel öğretim uygulamalarına dönmesine teşvik ettiğini ifade etmiştir. Ayrıca, programın ön gördüğü alternatif değerlendirme araçlarının amacına uygun şekilde kullanılmadığı, olumsuz tutum ve istenmeyen yeni uygulama biçimlerinin oluşmasına sebep olduğunu belirtmiştir. Program değişikliği ile birlikte öğretmenlerin derslerinde kullandığ değiştiği açıkça görülmektedir. Matematik öğretmenleri 2005 yılından sonra nadir olarak klasik yazılı sınavları ölçme aracı olarak kullandıkları belirtmişlerdir. Öğretmenlerin geleneksel ölçme aracı olan klasik yazılı sınavları büyük oranda hâlâ kullanmaya devam ettikleri görülmektedir. Bu sonuç ile uyumlu olan çalışmalar mevcuttur (Aş1k, 2009; Bal, 2009; Çoban-Torçuk, 2008; İyiol, 2011; Orbeyi, 2007; Yılmaz, 2006; Watt, 2005). Öğretmenlerin en sık kullandığı ölçme aracı çoktan seçmeli 
sorulardan oluşan test tipi ölçme araçları olduğu görülmektedir. Bu sonuçlarda liselere yerleştirme sınavlarının test tarzında yapılması ve iyi okullara yerleşme yarışının gittikçe artmasının etkili olduğu düşünülmektedir. Araştırmaya katılan öğretmenlerin hepsinin çoktan seçmeli soruları sık kullandıkları görülmektedir. İyiol (2011), araştırmasına katılan öğretmenlerin en sık kullandıkları ölçme araçları arasında çoktan seçmeli testler (\%81) yer almaktadır. Araştırma diğer bazı çalışmalarla uyumluluk göstermektedir (Aş1k, 2009; Bal, 2009; Flemming ve Malone, 1983; Orbeyi, 2007; Watt, 2005).

2005 yılı matematik programı ile birlikte öğretmenlerin ölçme araçlarında değişik soru türlerine yer verdikleri gözlenmektedir. Doğru yanlış sorularını (\%75) diğer soru türlerine göre öğretmenlerin daha çok tercih ettiği görülürken; eşleştirmeli $(\% 20)$ ve boşluk doldurmalı soruları $(\% 12,5)$ kullanan öğretmenlerin oranının daha az olduğu görülmektedir. Dağlar (2008)'ın araştırması ise öğretmenlerin sınavlarında değişik soru türlerine yenilenen program ile birlikte yer verdiklerini söylemektir.

Yenilenen matematik programında ölçme araçlarının çeşitliliğinin arttığı görülmekle beraber öğretimde bu araçların etkin şekilde kullanılması istenmektedir. Açık uçlu sorular bunlardan bir tanesidir. Singapur ve Türkiye'nin TIMSS'e göre öğretim programlarını karşılaştırdığı araştırmasında Aslan (2005), Singapur'daki genel sınavların açık uçlu ve çoktan seçmeli sorulardan oluştuğunu belirterek öğrencilerin kendilerini doğru ifade edebilmeleri ve detaylı bir değerlendirmenin yapılabilmesi için sınavlarda açık uçlu sorulara yer verilmesi gerektiğini belirtmektedir. Ayrıca açık uçlu soruların düzenli olarak kullanıldığında öğrencilerin akıl yürütme becerisi ile kelime, diyagram ve resimler arasındaki ilişkilerin geliştiği gibi öğretmenlerin kendi mesleki tecrübelerine katkısının olduğu görülmüştür (Akay, Soybaş ve Argün, 2006). Öğretmenlerin açık uçlu soruları kullanma ve değerlendirmesinin yapılması hakkında bilgi eksikliklerinin olduğu düşünülmektedir.

Çalışmaya katılan öğretmenler alternatif ölçme araçlarından tutum ölçekleri, öz değerlendirme, akran değerlendirmeyi kullanmadıklarını belirtmişlerdir. Birgin (2010), çalışmasında bu ölçme araçlarının en az sıklıkta kullanıldığını belirtmekte iken Taşpınar ve Halat (2009), öz değerlendirmenin yeterli düzeyde sinıflarda uygulandığını, akran değerlendirmenin ise sınıflarda yeterli düzeyde uygulanmadığını söylemektedir. Avcu ve Yenilmez (2011) ise akran değerlendirmenin kullanılmadığını belirtmektedirler. Araştırmaya katılan öğretmenler bu değerlendirme araçlarını kullanmadıklarını belirtmişlerdir. Araştırmayı destekleyen diğer çalışmalar da mevcuttur (Aşık, 2009; Çoban-Torçuk, 2008; Erdal, 2007; İyiol, 2011). Öğretmenler için bu ölçme araçları ile ilgili olarak iş yükü, zaman kaybı, nasıl kullanıldıklarına dair bilgi eksikliklerinin olması, gereksiz olarak görülmesi, alternatif ölçme araçlarının değerlendirilmesinin zorlukları, ölçütlerin çok olmasından dolayı olumsuz görüşe sahiptirler.

Araştırma 2005 yılı ilköğretim matematik ikinci kademe sınıflarında ilk defa uygulanan öğrenci merkezli yaklaşım ile hazırlanan 6-8. sınıflar matematik dersi öğretim programını kapsamaktadır. 
Daha sonraki yıllarda yayınlanan ortaokul matematik dersi öğretim programları bu çalışma kapsamına dahil edilmemiştir.

\section{KAYNAKÇA}

Açıkgöz, K.Ü. (2003). Aktif öğrenme. İzmir: Eğitim Dünyası.

Akay, H. (2006). Problem kurma yaklaşımı ile yapılan matematik öğretiminin öğrencilerin akademik başarısı, problem çözme becerisi ve yaratıcılı̆̆ üzerindeki etkisinin incelenmesi. Doktora Tezi, Gazi Üniversitesi Eğitim Bilimleri Enstitüsü, Ankara.

Akay, H., Soybaş, D. \& Argün, Z. (2006). Problem kurma deneyimleri ve matematik öğretiminde açık-uçlu soruların kullanımı. Kastamonu Ë̆itim Dergisi, 14(1), 129-146.

Akınoğlu, O. (2005). Türkiye'de uygulanan ve değişen eğitim programlarının psikolojik temelleri. Marmara Üniversitesi Atatürk Eğitim Fakültesi Eğitim Bilimleri Dergisi, 22(22), 31-45.

Akkoyunlu, B. (1996). Bilgisayar okuryazarlığı yeterlilikleri ile mevcut ders programlarının kaynaştırılmasının öğrenci başarı ve tutumlarına etkisi. Hacettepe Üniversitesi Ĕgitim Fakültesi Dergisi, 13(12), 127-129.

Alan, C. (2009). İlköğretim 5. sınıf öğrencilerinin matematik derslerinde problem çözme sürecine yönelik görüşleri: Nitel bir çalışma. Yüksek Lisans Tezi, Eskişehir Osmangazi Üniversitesi Sosyal Bilimler Enstitüsü, Eskişehir.

Albayrak, M. (1996). İlköğretim matematik dersi amaçlarının gerçekleşmeme nedenleri. Pamukkale Üniversitesi Ĕ̈itim Fakültesi Dergisi, 6, 80-85.

Altun, M. (2004). Matematik ve ögretimi. Bursa: Alfa.

Aslan, F. (2005). Türkiye ve Singapur fen bilgisi öğretim programlarının TIMSS-R'ye göre karşılaş̧tırılması. Yüksek Lisans Tezi, Hacettepe Üniversitesi Sosyal Bilimler Enstitüsü, Ankara.

Aşık, İ. (2009). Matematik öğretmenlerinin ölçme değerlendirme araçlarını kullanabilme düzeyleri ve yaklaşımları. Yüksek Lisans Tezi, Marmara Üniversitesi Eğitim Bilimleri Enstitüsü, İstanbul.

Avcu, T. \& Yenilmez, K. (2011). Yedinci sınıf matematik dersi öğretim programının öğretmen görüşlerine dayalı olarak değerlendirilmesi. E-Journal of New Sciences Academy, 6(1), 1-19.

Babadogan, C., \& Olkun, S. (2006). Program development models and reform in Turkish primary school mathematics curriculum. International Journal for Mathematics Teaching and Learning. http://www.cimt.plymouth.ac.uk/journal/default.htm.

Baki, A. (2003). Okul matematiğinde ne öğretelim nasıl öğretelim? MatematikçilerBülteni, 2, 13-16.

$\mathrm{Bal}$, P. (2009). Illköğretim 5. sinuf matematik öğretiminde uygulanan ölçme ve değerlendirme yaklaşımlarının öğretmen ve öğrenci görüşleri doğrultusunda değerlendirilmesi. Doktora Tezi, Çukurova Üniversitesi Sosyal Bilimler Enstitüsü, Adana.

Benavot, A. (1992). Curricular content, educational expansion, and economic growth. Comparative Education Review, 36(2), 150-174.

Birgin, O. (2010). 4-5. sınıf matematik öğretim programinda öngörülen ölçme ve değerlendirme yaklaşımlarının öğretmenler tarafindan uygulanabilirliği. Doktora Tezi, Karadeniz Teknik Üniversitesi Fen Bilimleri Enstitüsü, Trabzon.

Bransford J. D. \& Brown S. J, (1999). How peoeple learn. Washington D.C: National Academy. 
Budak, M. \& Okur, M. (2012). 2005 ilköğretim matematik dersi 6-8. sınıflar öğretim programına ilişkin öğretmen görüşleri. International Journal of New Trends In Arts, Sports \& Science Education, 1(4), $8-22$.

Büyüköztürk, Ş., Kılıç-Çakmak, E., Akgün, Ö. E., Karadeniz, Ş. \& Demirel, F. (2012). Bilimsel araştırma yöntemleri. Ankara: Pegem.

Çoban-Torçuk, F. (2008). 2006-2007 eğitim öğretim yll ilköğretim 6. sinlf matematik dersi öğretim programının ölçme ve değerlendirme boyutunun uygulama düzeyinin incelenmesi. Yüksek Lisans Tezi, Muğla Üniversitesi Sosyal Bilimler Enstitüsü, Muğla.

Dağlar, S. (2008). 2005 yılı ilköğretim 6. sınıf matematik dersi programının değerlendirilmesi üzerine bir çalı̧̧ma. Yüksek Lisans Tezi, Celal Bayar Üniversitesi Sosyal Bilimler Enstitüsü, Manisa.

Dickerson, V. M. (1999). The impact of promlem-posing instruction on the mathematical problem-solving achievement of seventh graders. Unpublished Ph.D Dissertation, University of Emory, Atlanta.

English, L. D., \& Halford, G. S. (2012). Mathematics education: Models and processes. Routledge.

Fer, S. (2005). 1923 yılından günümüze cumhuriyet dönemi ilköğretim programları üzerine bir inceleme. Cumhuriyet Dönemi Eğitim Politikaları Sempozyumu (5-9 Aralık 2005)

Flemming, M. L. \& Malone, M. R. (1983). The relationship of student characteristics and student performance as viewed by meta analysis research. Journal of Research in Science Teaching, 20, 481-495.

İyiol, F. F. (2011). İlköğretim 8. sinlf matematik programinın öğretmenlerin görüşlerine göre değerlendirilmesi. Yüksek Lisans Tezi, Selçuk Üniversitesi Eğitim Bilimleri Enstitüsü, Konya.

Kablan, Z. (2011). İlköğretim matematik öğretim programının değerlendirilmesine yönelik araştırmaların analizi. İlköğretim Online, 10(3), 1160-1177.

King, M. N. (1994). The qualitative research interview. In C. Cassell \& G. Symon (eds.). Qualitative methods in organisational research. A Practical Guide. London: Sage.

Marsh, C. J. \& Willis, G. (2007). Curriculum: Alternative approaches, ongoing issues. New Jersey: Pearson Prentice Hall.

Maxwell, J. A. (1992). Understanding and validity in qualitative research. Harvard Educational Review, 62(3), 279-301.

Millî Eğitim Bakanlığ1 (2005). Illköğretim matematik 6-8. sinıflar öğretim programı kitabı. Millî Eğitim Bakanlığı Talim ve Terbiye Kurulu Başkanlığı, Ankara.

National Counsil of Teachers Mathematics [NCTM], (2000). Principles and standarts for school mathematics. Reston, Va. The Ontario Curriculum Gradaes 1-8 (2005). http://www.edu. gov.on.ca/eng.

Orbeyi, S. (2007). Illköğretim matematik dersi öğretim programı'nın öğretmen görüşlerine dayalı olarak değerlendirilmesi. Yüksek Lisans Tezi, Çanakkale Onsekiz Mart Üniversitesi Sosyal Bilimler Enstitüsü, Çanakkale.

Orbeyi, S., \& Güven, B. (2008). Yeni ilköğretim matematik dersi öğretim programı'nın değerlendirme öğesine ilişkin öğretmen görüşleri. Eğitimde Kuram ve Uygulama, 4(1), 133-147. 
Ören, Z. T. (2010). İlköğretim 8. sinlf yeni matematik müfredatının matematik ögretmenlerinin görüşleri ışığında incelenmesi. Yüksek Lisans Tezi, Marmara Üniversitesi Eğitim Bilimleri Enstitüsü, İstanbul.

Özdemir, S. M. (2009). Eğitimde program değerlendirme ve Türkiye'de eğitim programlarını değerlendirme çalışmalarının incelenmesi. Yüzüncü Yıl Üniversitesi Eğitim Fakültesi Dergisi, 6(2), 126-149.

Romberg, T. A. \& Sharfer, M. C. (2003). Mathematics in context-prelimery evidence about student outcome. Lawrence Erlbaum Associates: N.J.

Sezgin-Memnun, D. (2013). Türkiye'deki Cumhuriyet dönemi ilköğretim matematik programlarına genel bir bakış. Mehmet Akif Ersoy Üniversitesi Eğitim Fakültesi Dergisi, 13(25), 71-91.

Silver, E. A. \& Cai J., (1996). An analysis of arithmetic problem posing by middle school students. Journal for Research in Mathematics Education, 27, 521-539.

Taşpınar, M. \& Halat, E. (2009). Yeni ilköğretim 6. sınıf matematik programının ölçme değerlendirme kısmının öğrenci görüşleri doğrultusunda incelenmesi. Uludă̆ Üniversitesi Eğitim Fakültesi Dergisi, XXII(2), 551-572.

Turhan, B. (2011). Problem kurma yaklaşımı ile gerçekleştirilen matematik öğretiminin ilköğretim 6. sınıf ögrrencilerinin problem çözme başarıları, problem kurma becerileri ve matematiğe yönelik görüşlerine etkisinin incelenmesi. Yüksek Lisans Tezi, Anadolu Üniversitesi Eğitim Bilimleri Enstitüsü, Eskişehir.

Tutty, L. M., Rothery, M. A. \& Grinnell, R. M. (1996). Qualitative research for social workers. Needham heights. MA: Allyn \& Bacon.

Ulutaş, S. \& Erman, M. (2011). Cumhuriyetin kuruluşundan günümüze Türkiye'de uygulanmış olan ilkokul, ortaokul ve ilköğretim okulları öğretim programlarında ölçme ve değerlendirme. Eğitimde ve Psikolojide Ölçme ve Değerlendirme Dergisi, 2(1), 148-154.

Umay, A. (1996). Matematik eğitimi ve ölçülmesi. Hacettepe Üniversitesi Eğitim Fakültesi Dergisi, 12, 145-149.

Uşun, S., \& Karagöz, E. (2009). İlköğretim II. Kademe matematik dersi öğretim programının öğretmen görüşleri doğrultusunda değerlendirilmesi. Muğla Üniversitesi Sosyal Bilimler Enstitüsü Dergisi, 22, 101-116.

Yayan, B. (2010). Student and teacher characteristics related to problem solving skills of the sixth grade Turkısh students. Doktora Tezi, Orta Doğu Teknik Üniversitesi Fen Bilimleri Enstitüsü, Ankara.

Yazıc1, E. (2009). Illköğretim matematik dersi 6. sınıf öğretim programı'nın değerlendirilmesi üzerine bir çalışma. Doktora Tezi, Selçuk Üniversitesi Fen Bilimleri Enstitüsü, Konya.

Yenilmez, K. \& Sölpük, N. (2014). Matematik dersi öğretim programı ile ilgili tezlerin incelenmesi (20042013). Ĕgitim ve Öğretim Araştırmaları Dergisi, 3(2), 33-42.

Yıldırım, A. \& Şimşek, H. (2011). Sosyal bilimlerde nitel araştırma yöntemleri. Ankara: Seçkin.

Yılmaz, T. (2006). Yenilenen 5. sınıf matematik programı hakkında öğretmen görüşleri. Yüksek Lisans Tezi, Sakarya Üniversitesi Sosyal Bilimler Enstitüsü, Sakarya.

Watt, H. (2005). Attitudes to the use of alternative assessment methods in mathematics: A study with secondary mathematics teacher in Sydney. Australia Educational Studies in Mathematics, 58(1), 2144. 


\section{EXTENDED ABSTRACT}

Purpose and Significance: Mathematics has an important place in teaching programs in improving the quality of education (Sezgin-Memnun, 2013). Since 1924, the program development studies have been continuing in our country. Subsequently, significant changes were made in the programs in 1926, 1936, 1948, 1954, 1968, 1982, 1990 and 2004 (Ulutaş and Erman, 2011)

Curricula need continuous evaluation and revision to increase their efficiency and to contribute to their development. The reason for it is that the degree to which a curriculum applied is effective, whether or not it continues to serve to the purpose and determining its lacks guide the effectiveness of a curriculum (Marsh and Willis, 2007). Thus, mathematics curricula should be examined and systematically revised at certain intervals (National Council of Teachers of Mathematics [NCTM], 2000). Therefore, it intends to analyse the 2005 mathematics curriculum- which is considered to be student-centred- by investigating the skills it intends to instil in the $6^{\text {th }}-8^{\text {th }}$ graders and the frequency of using the teaching approaches and the evaluation and measurement approaches available in the curriculum. In this context, it seeks answers to the following research questions:

1. What are primary education mathematics teachers' views on the mathematical process skills (associating, communication, reasoning, problem-solving) available in the mathematics curriculum $\left(6^{\text {th }}-8^{\text {th }}\right.$ grades $)$ ?

2. What are primary education mathematics teachers' views on the teaching approaches available in the mathematics curriculum $\left(6^{\text {th }}-8^{\text {th }}\right.$ grades $)$ ?

3. What are primary education mathematics teachers' views on the measurement and evaluation approaches available in the mathematics curriculum $\left(6^{\text {th }}-8^{\text {th }}\right.$ grades $)$ ?

Method: This study, which has qualitative design, intends to collect data by using the interview technique. It uses criterion sampling, a method of purposeful sampling method. The following criteria were set in the study: a) volunteering, b) being adequately informed of mathematics curricula and c) teaching at each grade level in grades 6-8. The participants were demanded that they had at least ten year teaching experience, that they were knowledgeable about the mathematics curricula prior to the 2005 curriculum beside it and that they had used them in their teaching; because it was important in demonstrating the difference of the 2005 curriculum from the others clearly, in making the comparison between them and in evaluating them. Interview questions were prepared for the study and they were built on the basis of literature review. The interview questions were prepared by considering the mathematical skills that the mathematics curriculum intended to instil in students, the learning approach and the evaluation and measurement approach in the curriculum. The data were analysed by using the NVivo 10 Qualitative Analysis Programme.

Discussion and Conclusion: This study aimed to analyse mathematics teachers' views on the mathematical process skills that students were expected to gain the mathematics curriculum and the 
teaching approaches and the measurement and evaluation approaches in the curriculum. Hence, 24 mathematics teachers' views were obtained through semi-structured interviews. On examining the teachers' views on associating with daily life, it was found that the $5^{\text {th }}$ and $6^{\text {th }}$ graders made associations with daily life more easily, but that they had more and more difficulty in associating as the grade level rose- that is to say, in the $7^{\text {th }}$ and $8^{\text {th }}$ grades. An examination of skills of associating with other courses showed that $50 \%$ of mathematics teachers held the view that students were inadequate in associating mathematics with other courses. Teachers who thought so stated that students had difficulty in transferring mathematics into other courses. On examining teachers' views on the skills of associating within the course, it was found that $37 \%$ of the teachers said that associating within the course- that is to say, spiral structure- was positive with the renewed curriculum while $33 \%$ of them said that they had negative views on the issue. The teachers who had positive views about teaching spirally said that it was positive in that students had the opportunity to repeat the subjects they could not learn and thus to compensate for those subjects and in that connections between subjects could be continuously set up. The participating teachers were asked how they presented the stages of problem solving in their classes to interpret the effects of the mathematics curricula on the development of students' problem-solving skills on the basis of teachers' views. Consequently, $37.5 \%$ of the participants said that they presented the problem-solving stages in their classes whereas $74.3 \%$ of them said that they occasionally used the stages of problem solving and $17.2 \%$ said that they did not use the stages of problem solving. Those who said that they occasionally used the stages of problem solving gave such responses as "there were times when I generally used them" and "not very often". In relation to the problems the teachers encountered in using the stages of problem solving, the teachers said that those stages seemed to be stories to students and thus they considered them unnecessary, that students were solution-oriented and therefore they directly moved on to the solution by making plans in their mind, that students solved problems through memorisation with their habits coming from primary school and that they did not highlight different strategies. Yet, it was concluded that teachers generally did not use the stages of problem solving although they found the 2005 curriculum positive in that it offered new perspectives to problem solving strategies through different strategies. Teachers stated, in relation to students' ability to generate different solution strategies, that the students who had mathematical capability were generally adequate in generating strategies of solution while other students were inadequate in this respect. In conclusion, it may be stated that teachers did not present the four-phased stages of problem solving (understanding the problem, planning, implementing the plan, checking the accuracy of the solution) in their classes. The teachers stated that the did not teach those stages in their classes for such reasons as that nationally held examinations did not include problem posing activities, that such activities were not included in text books sufficiently, that the subject was not taught in special courses, that students considered the subject as a burden to them and that it was considered as waste of time. Although three of the participants said that they did problem posing activities in their classes, they considered themselves 
inadequate in making students gain the ability to make comments. Here, the interpretation could be that problem posing- which was one of the main objectives of problem-solving skill which was the basic skill in mathematics curriculum- was not taught in mathematics classes. It was observed that teachers included different types of questions in their measurement instruments with the 2005 mathematics curriculum. Thus, while they were found to prefer true-false questions more (18\%) than other types, they were found to use matching (20\%) and fill in the blanks (12.5\%) types of questions less often. 